\title{
New Media and Nationalism in Indonesia: An Analysis of Discursive Nationalism in Online News and Social Media after the 2019 Indonesian Presidential Election
}

\author{
DIDIK HARYADI SANTOSO \\ Universitas Mercu Buana Yogyakarta
}

\begin{abstract}
Nationalism is an issue that is often contested in a political rally in various countries. Nationalism is generally used to describe two phenomena: first, the attitude of members of the nation when they care about their national identity. Second, it can be defined as any action performed by members of the nation to sustain their self-determination or political sovereignty. In the era of conventional media, nationalism was created from the dynamics of physical interaction, human to human. However, in the new media era, nationalism has turned into "human to technology to human". This leads to a dynamic that never happened before. To capture this, online news and social media data were captured using the SNA (Social Network Analysis) method, in collaboration with astramaya.id that saw 19 online news items listed. Data were also collected from Facebook (3,376 mentions), Instagram (3,417 mentions), Twitter (160,432 mentions), and YouTube (1,699 mentions). The time frame, July 2019 to July 2020, takes into account the high level of discussion on nationalism after the presidential election and Covid19. This research found that: first, Indonesia's Nationalism has divided into two caps; second, a nonhuman social media account gives a significant contribution to these cleavages; third, primordial sentiments take determining effect for every actor in generating cleavage.
\end{abstract}

Keywords: Nationalism, online news, social media, social network analysis, Indonesia.

\section{INTRODUCTION}

The issue of nationalism has drawn attention for politicians, state managers, academics, and even the media. Nationalism is notably enrolled as a driver for a state. Moreover, the issue of nationalism is often contested in political rallies in various countries. In Gellner's terminology, nationalism is defined as the "principle that the political and national unit should be congruent" with the primary objective of gaining political legitimacy (Gellner, 1983). In other terms, nationalism is understood as "territorially based identities" (Eriksen, 2007). Usually institutionalized into the education system, state ideology and the practice of daily social life occurs hegemonically as well as in a natural process (Edensor, 2002). In contrast, Mischevic (2018) believed that nationalism required two features: first, the attitude of the members of the nation when they care about their national identity. Second, any sort of nation member's action in sustaining their self-determination or political sovereignty. However, it requires knowledge of movements and a collective awareness process about the meaning of nationalism. In Billig's terminology (1995), nationalism lies in the process of internalization of collective knowledge.

In a global context, the increasing turbulence at the socio-political level is often intertwined with the fluctuation of nationalism. In China, for instance, nationalism and media helped increase the stability and legitimacy of the political system through the consumption and production of news (Hyun \& Kim, 2015). Although social media has created a significant difference, the use of Weibo in China, for example, as a medium to convey political information and nationalism, tends to be negatively associated with the support of the 
political system and consequently created a negative effect on the issue of nationalism. Meanwhile, WeChat is used to gain political mileage and has a positive effect on nationalism, thereby increasing support for the national political system (Wang \& Kobayashi, 2020).

In the era of conventional media, nationalism is created from the dynamics of physical interaction and human to human. However, in the era of new media, nationalism has turned into "human to technology to human". This does not only lead to changes in the concept of nationalism, it also provides space for non-human agents (bots, fan page, trolls) to intervene in the concept of nationalism.

The production of content about nationalism also varies. Previously, it was dominated by the state, political elites, and institutionally, but in the era of new media, more nationalist content was produced by new media actors and carried out individually. In addition, the debate and contestation on the meaning of nationalism also have experienced shifts and changes in the new media. In the past, a sense of nationalism could be present in shared moments or physical events (Kecmanovic, 1996). However, in the new media era, nationalism is virtually mediated, and there are negotiations and discussion of meaning.

Most of the studies on nationalism focus on explaining the theme of the behavior of the community, nation, or state. These are the themes that dominated research on nationalism. A research on nationalism in Indonesia has been conducted by Edward Aspinall. In his research, he analysed Indonesia's new nationalism by dividing nationalism into economic nationalism, cultural nationalism, and territorial nationalism. Aspinall also explained the new characteristics of contemporary nationalism, namely non-ideological and non-intellectual (Aspinall, 2015). David M. Bourchier (2019), in the context of nationalism in Indonesia, found that there was a shift in ideology and nationalism after President Soeharto. The shift was from democratic norms to conservative and religious nationalism.

Research related to the correlation between nationalism, modern media, and social media has been carried out by several researchers in the world. For example, Hyun and Kim (2015) researched online communication and populist nationalism in China. The research showed that online political expression facilitated by news can increase support for the existing socio-political system, either directly or indirectly, through nationalism (Hyun \& Kim, 2015). Other research shows how mass media affects the public's perceptions of nationalism. Research conducted by Guo, Cheong and Chen (2007) found that the attractiveness of mass media to form public perceptions of nationalism worked effectively. In addition, this research also showed that attention to the news in mass media has a direct effect on nationalism.

Our research is different from previous studies. This research focuses on two mediums simultaneously, social media and online news. There has been no research on nationalism in new media that combines big data from social media and online news. In addition, the use of the SNA (Social Network Analysis) method provides novelty in research on nationalism in virtual spaces. This study aims to understand the production, consumption, and contestation of actors about nationalism in social media and on online news.

\section{LITERATURE REVIEW OR RESEARCH BACKGROUND}

The study of nationalism predominantly embarks from the socio-historical inquiry; however, philosophical approach also often accompanies the works. Afaqi (2016), for example, addresses the historical roots of Indonesian nationalism by employing literature study to strengthen nationalism among the young generation. He suggests that the awareness against a global force that may contain foreign value should be put in a sceptic and may derail 
Indonesian value. By reviewing historical roots on the way Indonesia acquired its nationalism, Afaqi has shown that even nationalism can be renegotiated through the existing global value invasion against youth.

Following the same historical perspective as Afaqi, Muhammad Ridhlo Al Qodri Sri Utomo's critical discourse study gives a detailed analysis on how the notion of nationalism entangled with colonial and geopolitical context in determining self-concept of Indonesian citizen. Sri Utomo unpacks media discourses related to nationalism and Indonesian selfconcept through books, colonial newspapers and public ads, ranging from Dutch colonialism, Japan invasion, Sukarno's Old Order to Soeharto's New Order. Sri Utomo highlighted that these global powers competed with each other in shaping citizen's self-concept which reflects a specific set of ideas on nationalism (Utomo, 2020).

However, the challenge circling nationalism is not merely globalization. Kusumawardani and Faturochman (2004) noticed that the derailment of nationalism within the contemporary generation might lead to the forthcoming disintegration and separation. They argued that it is necessary to put nationalism as a sustainable communitarian project. Global forces may entail, whether implicitly or explicitly, renegotiation of feelings of nationalism within society. Meanwhile, deterioration of nationalism in Indonesia has been a crucial factor in determining the sustainability and resistance of Indonesian society against a communitarian threat, whether values, ideologies or manner, which may affect identity configuration.

The implication, politically, can be seen in the works of Hadiz (2016). He noted that the feeling of being marginalized from economic and social development drives Islamic populism, a reaction that tries to redefine self-sovereignty based on religious primordialism. It establishes an antagonistic outline depriving political elites, the rich, Chinese, and Christians from the inclusive manner of Indonesia nationalism by bypassing the democratic process. Mietzner (2020) also put similar remarks but in more nuanced insights. He believed that horizontal disintegration that populism had proposed occurred from the existing social and economic conditions that are already equivalent. Thus, it can be inferred that the factor that determines nationalism does not only come from foreign force or from abstract ideas, but emerges from the concrete social condition of the identities that inhibit Indonesia.

Nevertheless, the emergence of digital technology undeniably gives a new form of nationalism construction process in society. In a bigger context, this may be intertwined with state-sponsored political views, grassroots imaginations, news and discursive streams in the media, and the dynamics of identities in a nation. In China, for example, online communication helped build trust towards status-quo and enhance nationalism (Hyun \& Kim, 2015). In Ukraine, the alternative interpretation of nationalism is deployed to influence electoral votes of far-rights parties by using computer-mediated dissemination (Doroshenko et al., 2018). Similar features also took place in Sri Lanka but with a more insidious gesture. Sinhala-Buddhist promotes ethno nationalism in social media to marginalize Muslims (Ivarsson, 2018).

Pertinent to that, there is a significant shift in the way society negotiates the concept of nationalism due to the emerging digital transformation. However, that research provides no picture of the dynamics among actors, their interaction with each other and public discourse about nationalism. Following the gap, this research highlights the importance of further exploration by digging through Social Network Analysis to discover inter-actors and 
discursive relations. In this given study, we analyse the dynamics of nationalism concept in the Indonesian digital realm.

\section{Data Collection}

\section{METHODOLOGY}

Online news and social media data were taken using web crawlers and the SNA method, in collaboration with astramaya.id. The number of online news sites are 19 (see Figure 1: distribution by online news). Data were collected from social media: Facebook (3,376 mentions), Instagram (3,417 mentions), Twitter (160,432 mentions), and YouTube (1,699 mentions). The time frame chosen was from July 2019 to July 2020 into account the high level of discussion on nationalism after the presidential election and Covid-19.

To collect data from social media and online news, these keywords were used: nasionalisme/nationalism, pancasila, NKRI Harga Mati/state integrity, Pemilihan Presiden/Presidential Election. Data collection in this study is based on two features: (1) Nationalism themes and keywords (2) The data collection period is from July 2019 to July 2020.

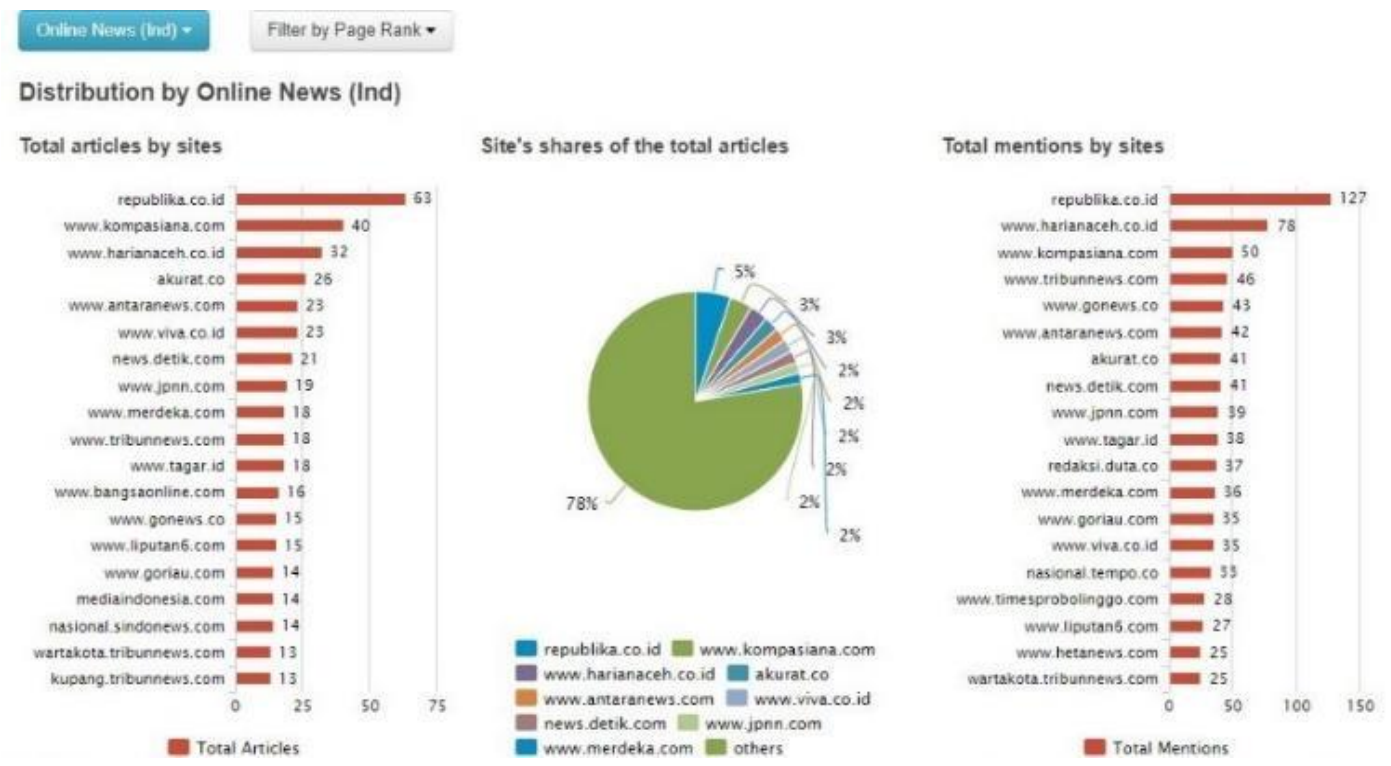

Figure 1: Distribution of online news (Source: SNA (Social Network Analysis) method, in collaboration with astramaya.id)
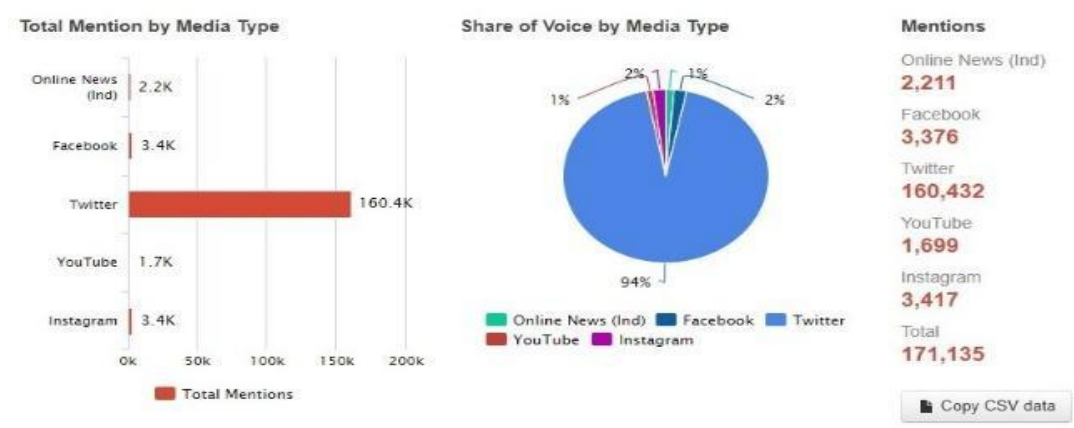

Figure 2: Total mention by media type SNA (Social Network Analysis) method, in collaboration with astramaya.id) 


\section{RESULTS AND DISCUSSION \\ Nationalism and Social Transformation in Indonesia}

Although nationalism has conceptually been known as a never-ending debate, the discussion on nationalism must be resolved prior to putting it into account. Nationalism can be defined by referring to these two lines (Mischevic, 2018): first, the attitude of the members of the nation when they care about their national identity; second, any sort of the nation members' actions in sustaining their self-determination or political sovereignty. Following this line, ethnicity, religion, culture, or any primordial base provides fundamental ties of the existing nationalism in a particular country (Mischevic, 2018). Thus, the societal determination process was inevitably drawing communitarian discussion in public life. The sort of identity, social capital, domination, and alienation may influence how the public discussion went and how the outcome might determine an operating-consensus for each identity.

British Malaya and Dutch East Indies in the early twentieth century, for example, were noted as a regional basis for the myriad of identities due to international voyages. British anthropologist, John Sydenham Furnivall observed that the existing identities, Chinese, Indian, Arabian and Malayan, in British and Dutch colonial land were accompanied by a castelike division of labour, in which ethnoreligious groups play different economic roles (Hefner, 2001). However, Furnivall also noticed that this social configuration was the most unsettled political trait because of a lack of common social will (Hefner, 2001). To maintain communal well-being, Furnivall argues that each ethno-religious group has to share taste, value, and identities that an individual experiences as a member of that society and can satisfy that society (Hefner, 2001).

Furnivall's outline of British and Dutch colonial area illustrates a land which has yet to have a communal identity and far from having the imagination of communal nationalism. However, the imagination of nationalism among the myriad groups of identity, hereinafter marked as 'independence', started to take place. As Snouck Hurgronje (1994) points out that Arabs and Chinese were notably the overseas merchants and holding second-place social caste after Europeans which mostly enrolled as official administrations, while the natives were treated as the lowest-caste workers. Although western scholarship predominantly proposes these triadic social groups, the contributions of local rebellion-which took place in and by various provinces and methods-against colonial administrations should not be discredited from the way Indonesia then subsequently formulated its nationalism.

The struggle in composing national identity even escalated at the personal level. Geopolitical power namely Dutch colonialism and Japanese administration once contested for Indonesia's national identity by using newspaper ads, books, and commercial flyers as infiltrating mediums to shape Indonesian citizen's self-concept (Utomo, 2020). Subsequently, although Boedi Oetomo had given a notable cornerstone for Indonesia's national identity in 1908, the general condition of Indonesia's nationalism identity remained at the unstable settling until 1965. Thus, in the upcoming years, several important moments happened to continuously revisit the previous mould of Indonesia's nationalism.

One of the remarkable early phases of Indonesian nationalism is the orchestration of Sumpah Pemuda (Youth Pledge) in 1928, seventeen years before independence (Kusumawardani \& Faturochman, 2004). Sumpah Pemuda utilizes non-ethnocentric substances in an attempt to bind a myriad of identities and diverse historical backgrounds together. Yet, this momentum successfully enhances vigorous national spirit across Indonesia archipelagic communities, which entails an unstoppable will of being an independent nation 
in 1945. Thus, rather than to embark from a nativist spirit that may exclude Arabs, Chinese, and any foreign descent, the momentum of Sumpah Pemuda departs Indonesian nationalism based on a brand new national identity derived from various cultural elements. In addition, the existence of Dutch colonialism as a common enemy also gives a reason for all geographically inhibiting Indonesia to unite.

Nevertheless, after this novel national identity has succeeded in fostering Indonesia to obtain independence, Indonesia's nationalism lost its main unitary factor and urged to reformulate itself in order to cope with the upcoming nation-state challenge. In the subsequent regime after independence, particularly the New Order regime, some horizontal aspects such as ethno-socio-religious inequality in many parts of Indonesia are still left open. Besides that, the dusk of the New Order regime was coloured by its major corruptions among Soeharto's circle, which were notably from Chinese descent tycoon. Following this background, in the 1990s, Chinese were presumed as the icons of the wealthy (i.e., Tirtosudarmo \& Hadi, 2018; Tsai, 2011). The outcomes, therefore, as Jaques Bertrand noted (2004), were an unprecedented number of violence in the late 1990s. Numerous deaths and the destruction of private property took place during 1995 and 1996 in Situbondo, Tasikmalaya and other parts of Java due anti-Chinese sentiment.

In addition, from 1997 to 2002, the violent conflict claimed at least 10,000 souls (Bertrand, 2004). Some notable tragedies were the two surges of Dayak and Madurese conflict in 1996-97 and 2001, which made 1000 people victims and displaced hundreds of thousands of Madurese from West and Central Kalimantan (Bertrand, 2004). In Maluku, the war between Muslims and Christians took 5000 victims. In East Timor, 1000 lives were lost and 200,000 civilians displaced, then led to a referendum in August 1999. Also, in between 2000 and 2001, renewed confrontation between the Free Aceh Movement and Indonesian Armed Force in Aceh, approximately took 1800 lives. In the further East, Irian Jaya suffered similar bloodshed, occurred due to unsatisfying provincial development, which set out regional economic inequality (Bertrand, 2004).

Besides distributed conflicts in Indonesia, the dusk of New Order also left a wide opportunity for the Islamist force -- the Tarbiyyah movement -- to develop without enormous burden. This also includes the ghost of the communist party (PKI) and any similar leftist movement that are still haunting to this day (Mietzner, 2013). The triumph of Islamist surge in toppling down Basuki Cahaya Purnama (Ahok) at the 2016 Jakarta Gubernatorial Election, in which the torrent persists to this day, invigorated Islamic discourse.

In the midst of conservatives' turn, Soeharto's legacy, the ghost of PKI and antiChinese sentiments intertwined (Nadzir, Seftiani \& Permana, 2019). This includes intervening 2019 electoral discourse to delegitimize certain political credibility. Islamist, then, was promoting the redefinition of Indonesia's nationalism based on an Islamic paradigm. When Islamist surges merged with the Internet, it renegotiated the function of Internet to fit with their values, discourse and goals. Thus it affects the discourse in social media to only confirm beliefs of audiences in a wider scope (Humeira \& Sarwono, 2019).

However, although the formulation often claimed the nation is Indonesia, at the same time, Islamist refers to ummah as its true people, the rightful heir of Indonesia's sovereignty. Therefore, many observers commented that this is a sort of Islamic populism (Mietzner, 2020), which denies the existence or even antagonizing the others (Chinese and Christians) which rooted from romantic imaginations of corrupt tycoons, the horrific tragedy of 1965, and those deemed to deprive ummah of its rightful sovereignty. 
As a response against the alarming surge of Islamism, incumbent administrations disbanded Hizbut Tahrir Indonesia (HTI) in 2017; a foreign-based Islamist organization which aims to establish a khilafah; one from several Islamist coalition namely Islamic Defender Front (FPI), GNPF-MUI, and others. Since then, the contestation discourse of nationalist versus Islamism intensified on a new level. Nahdlatul Ulama, one of the prominent promoters of local-based nationalism, stands forward in amplifying the discourse of local and non-religious based nationalism. However, the endorsement of state-based nationalism is also perpetrated by secular stakeholders such as influencers, buzzers, local citizens, celebrities, politicians, and many others.

Following this elaboration, there are at least three remarkable periods in the development of nationalism in Indonesia. The first period is before and after independence. This period saw face-to-face interactions as its main negotiation platform: commercial links, cross-ethnic marriage, and any social occasions. In addition, the existence of Dutch colonialism also gives a unitary reason for the myriad of communities to decide their sovereign-fate, although this factor vanished soon after independence took place and urged more sophisticated nationalism formulation.

Second, the dusk of New Order provides a critical juncture for Indonesia's nationalism fate. Following this line, some of the primordial aspects are played, either naturally coincided or politically intended, to set social cleavages and leave an exploitable primordial wound. Third, the 2016 Jakarta Gubernatorial and 2019 Presidential Election was the tip of mounting social cleavages.

However, the first two points happened on a face-to-face occasion, while the last was orchestrated in a mediatized environment. Similar to Furnivall but in a different tone, Hefner (2018) noted that the availability of hoax, fake news, and the ability of digital technology in facilitating anonymity and obscuring the truth gives a new form of intervention against communitarian discussion of nationalism (Hefner, 2018). Such nefarious elements might contain demagoguery and less sincere substances that may pollute the form of nationalism. Here, Hefner noticed that there is a new operating-consensus within society in the way they supposedly treat a particular identity, and how their treatment may redefine the ideal and fair form of nationalism. In a nutshell, if a society reflects its operational-consensus based on polluted digital reality, then it is plausible for the operating-consensus to facilitate discriminative civility. For instance, discriminating Chinese may be deemed indiscriminate when it is derived from the polluted discussion.

Nevertheless, this mediatized realm is entirely different from the realm Furnivall previously commented on. Besides humans, the digital realm is inhibited by bots and trolls. Meaning humans or bots or the combination of both could organize behind the page or the account that we interact on. Oxford Internet Institute's research shows that this non-organic method has been used to hijack the worldwide political rehearsal (Woolley \& Howard, 2019), known as computational propaganda. A similar intervention was also found in Indonesia. The following elaboration shows that even the fundamental concept of nationalism in Indonesia has been hijacked by non-human agents and created an intriguing online debate about nationalism among citizens. 
Nationalism in Indonesia Digital Realm

The chart presents the results of Social Network Analysis (SNA) records on Tuesday, July 14, 2020 , on the topic of 'nationalism' in cyberspace. Unfortunately, due to limited capacity and time, the graph is unable to show a long-term pattern of nationalism development but envisages a one-day crawling sample. To provide a comprehensive picture of how nationalism is understood including who are the influential interpreters of nationalism, how is the dynamic, who are struggling for interpretation, and so on; frequent or marathon crawling is necessary for future research.

However, our current findings illustrate that there are three forms of understanding of nationalism in Indonesia, namely: Islamic nationalism, nationalism (which has a slight tendency to be chauvinistic), and sarcastic nationalism. This categorization may be unseen on the graphs, but theoretically available when uncovering the backgrounds and timelines of the most influential actors in online chats.

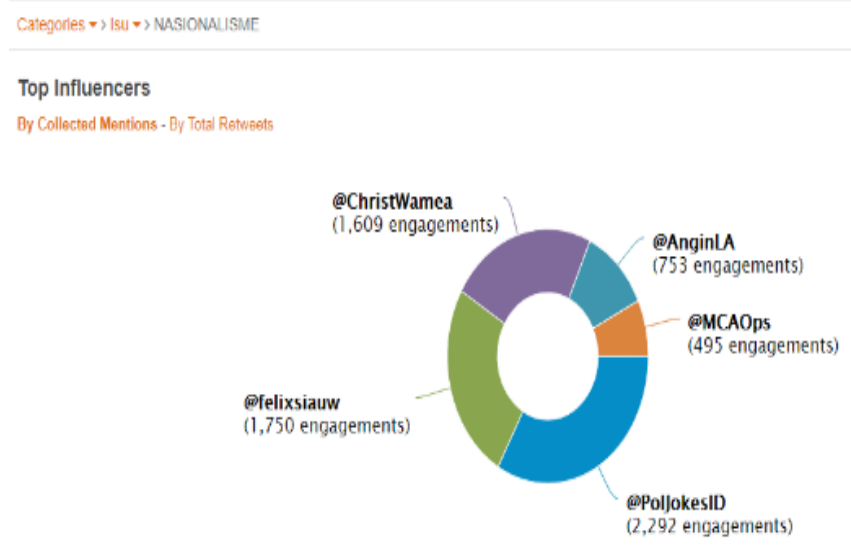

Figure 3: Five most influential account

Considering how influential cyberspace is to any conception in our minds, the graph above shows that the narrative of nationalism in cyberspace is dominated by Islamism propagators (Figure 3). Three of the five most influential accounts in carrying the narrative of nationalism are @felixsiauw, @MCAOps, and @AnginLA. All three are Islamist accounts with a commitment to Khilafah.

Nevertheless, there is a significant difference among the three: @felixsiauw is a cleric, @MCAOps has taken a role as a non-persona but collective army account, and @AnginLA is identified as a kind of buzzer operated by humans (not bots). In contrast to the three Islamic accounts, @ChristWamea is characterized as nationalism as well as pro-government nationalism. Meanwhile, @PolJokesID a meme fan page account containing sarcastic meme content about Indonesia's dynamics, ranging from infrastructure, elite signs, to ideological discourses. So, up to this point, there is at least a little picture of where nationalism in Indonesia is being drawn. 


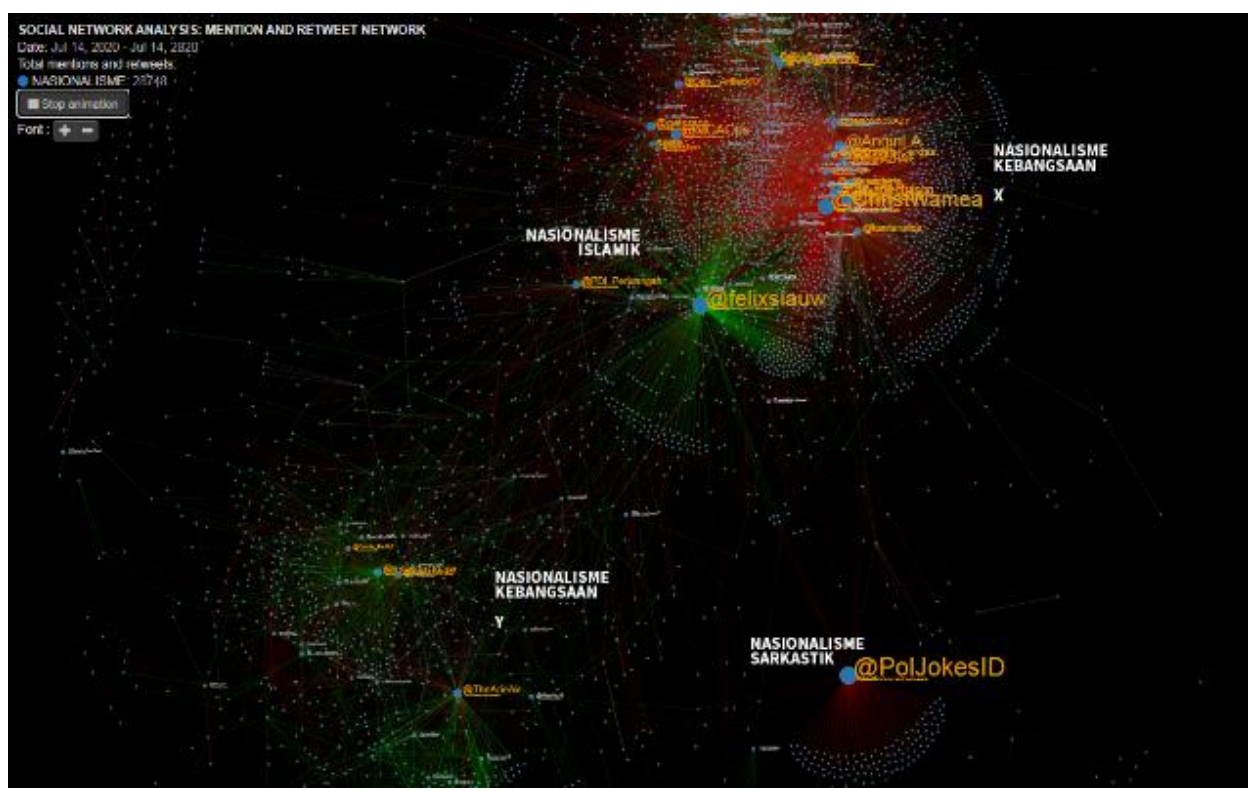

Figure 4: Network clusters of actors in Twitter debating about nationalism

Figure 4 shows the actors' relations in Twitter debates. The picture contains three clusters. The first cluster, the most tangled network, is the core field for the struggles of the discourse on nationalism. @ChristWamea, @MCAOps, @AnginLA and @felixsiauw are central for the dynamics of the cluster. It could be seen that there are red and green lines. The red line indicates negative sentiment, while the green line marks positive sentiment. The entanglement of this cluster indicates that the border area is an area of debate. However, green is more prominent on @felixsiauw's thread compared to the other three shafts. We argue that this is related to the type relationship the account has with its audience and the audience segmentation.

@felixsiauw as a personal account is colloquially known for targeting urban youth, of a certain educational background. Audiences who come from this background are often categorised as middle class. This audience segmentation, regardless of their preferred style of expression, is likely to be literate enough not to have no interest in consuming buzzerbased information. Thus, it can be seen that @felixsiauw's axis has a quite large number of green line nodes which are unattached to its opposite cluster. However, at a closer-look, @felixsiauw's axis has some nodes (dots) which: first, are connected to the debate on the axis of @ChristWamea, @MCAOps, and @AnginLA; second, are far connected to the lower left cluster (Nationalist nationalism cluster $\mathrm{Y}$ ).

Therefore, from @felixsiauw axis, there are several things that can be underlined: first, the conception of nationalism offered by @felixsiauw received a positive reception from most of the surrounding nods. Second, there are some @felixsiauw's audience who are quite comfortable sailing in a sea of negative-positive sentiments about nationalism. Third, only a few of @felixsiauw's audience have engaged with credible sources of information.

In contrast, @AnginLA, @ChrisWamea and @MCAOps, are surrounded by a large amount of negative sentiment. Although, in detail, behind the tangled red lines of the three shafts, there are faint green lines. Regardless of what they are promoting, troops, bots and buzzer accounts have varying quality of information, but have lower quality than the quality of information from personal accounts. The multitude of nods that surround and bridge the 
three axes reflect a group of audiences that are more impulsive and reactive to interpretations of Islamic nationalism and nationalism which originate from less credible references to nationalism. In Figure 2, there are two loci of Nationalism, namely: the locus of nationalism $X$ which collides directly with the locus of Islamic nationalism. In addition, there is a locus of nationalism $Y$ which has numerous nodes but does not significantly influence the dynamics of contested discourse online.

Locus of nationalist nationalism $\mathrm{Y}$ is not the only one that is not involved in the struggle for discourse, but the cluster of sarcastic nationalism is also included. The @PolJokesID shaft has several nods, but it is dominated by negative sentiment. @PolJokesID is a page that contains sarcastic memes that convey a sense of distrust, cynicism and scepticism towards discourse that represents nationalism in Indonesia, whether it is from an Islamic perspective or from a national perspective. The nods that flock to this axis are those who believe that Islamist nationalism is not sufficient to serve as a guideline, and nationalism is a mode of military and private alignment. Therefore, it can be concluded that the style of interpretation of Islamist nationalism and nationalist nationalism are the two interpretive styles that dominated public debate about the concept and direction of nationalism in Indonesia.

We argue that our public debate about nationalism should not be in this dichotomy. For example, in 1981, long before we had enough technology to see the chaos of online discourse, Abdurrahman Wahid once offered an embryo of an 'interpretive style' of nationalism that was more adequate than the nationalist interpretation that dominates the current debate over our digital space (Ramage, 1996). Without the ability to do so, they will lose relevance in the midst of the intellectual life of the nation. The most Indonesian value of all the values that the citizens of this nation share is the endless search for social change without severing ties with the past at all. We could just call it the quest for harmony.

However, transformative nationalism proposed by Wahid seems to have no cluster inside the SNA outlook. We argue that there are two reasons why transformative nationalism is not visible in the tangle of the SNA network on the issue of nationalism: First, transformative nationalism could actually exist, but on issues that are not in the spotlight like the other two types of nationalism; thus, the transformative nationalism was not placed in the SNA. Second, transformative nationalism may live in a small-circle of social movements that are often being underestimated, and have insufficient power sustained. Thus, the life of transformative nationalism tends to fluctuate and never truly acquires significant discursive attainment. A very different pattern can be seen as well as Islamic nationalism and nationalism occupy online discourses (refer Figure 5). 




Figure 5: Online news domination

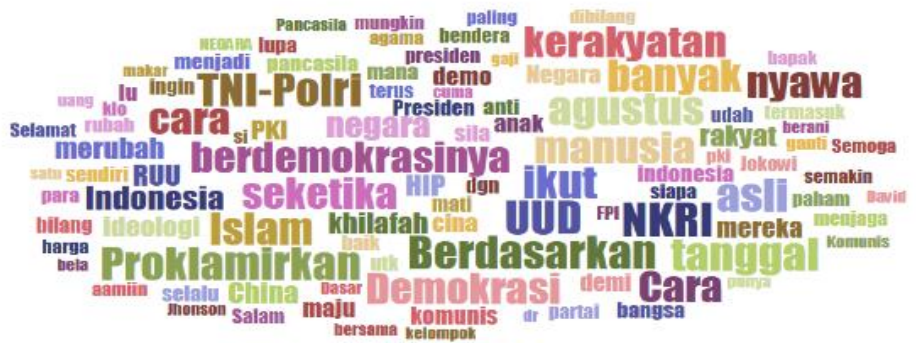

Figure 6: Word maps

In Figure 6, large-sized words reflect discursive domination, while the small-sized ones show less influence. The SNA result shows that our ideas on nationalism derived from a trichotomic share: the state-centric nationalism (NKRI, UUD, TNI-POLRI, HIP), the Islamist nationalism (Islam, Khilafah), and the ghost of left nationalism (communism, PKI, China).

In some cases (Nadzir, Seftiani \& Permana, 2019), nationalism is often used as a reason by nationalist and state-fanatics to legitimately put those whom criticize government with leftist tone under the label of 'traitor,' 'threat,' 'not loyal,' 'non-nationalist,' etc. At the same time, Islamist nationalism also often labels the leftist and initiators of social change as liberal, communist, immoral. After 75 years of independence, Indonesia's interpretations of nationalism are still trapped in antagonistic exegesis. This may be due to the legacy left by Suharto - the ghost of the leftist movement in Indonesian society. In addition, the existence of this ghost also provides certain benefits for those who have an interest in how Indonesia, Nationalism, and Pancasila should be interpreted. As a result, movements or discourses such as labour issues, women's rights, freedom of opinion, agrarian welfare, and any emancipatory agendas are tremendously difficult to thrive in Indonesia.

At the same time, Indonesia's infertility for progressive movements actually provided a conducive climate for the 90s Islamic tarbiyyah movement to flourish during the postreform era. The trend of hijrah, fundamentalism, and many partisan discourse are among the 
results of the legacy of the New Order. Thus, the nationalism that persists to this day occurred within two types of interpretation. When these two interpretations involve political interest, nationalism automatically turns into a vehicle for what Foucault (1988) remarked as the practice of power. The state as the most powerful actor clearly has a more favourable position in perpetuating knowledge compared to the groups that attempt to oppose it.

However, as discussed in the earlier section, this indicates a strong possibility that the country's competitors could pose a modest threat. The following portrait of SNA shows that the militaristic and state-centric knowledge of nationalism dominates online news. Meanwhile, as explained in the first part of this article, the accounts of nationalism promoters affiliated with the state are even less popular than those of nationalism promoters who come from Islamic groups (which in fact the cyber movement is composed by Islamic influencers, cyber troops, and bots). This means that there is a gap between what the state is trying to promote online and what is actually happening in the dynamics of social media.

Figure 6 shows that the knowledge of nationalism in online news offered by the state tends to be militaristic in colour. Nationalism is affiliated with security, stability, order and symbolic mystification. If anyone asks what nationalism is, the security apparatus has long been the interpreter of the reference, and the reference has been internalized by most educational institutions (starting from the elementary level to the high level). However, when can cultural observers, artists, leaders and followers of local religions, workers, farmers and students have the same authoritative space as the security forces when interpreting nationalism?

In conclusion, reflecting on the dynamics of nationalism's SNA which only lived out by two features, and most of the knowledge about nationalism that exists in that dynamic come from influencers and cyber troop accounts. So, it seems that we need to re-examine the concept of nationalism in the digital space, and formulate a strategy on how more credible information sources can compete with digital technology. Apart from that, we argue that; the nationalism portrayed by the SNA contains a possibility for political turmoil. This potential is indicated by the high impact of anger surrounding the issue of nationalism in the digital space.

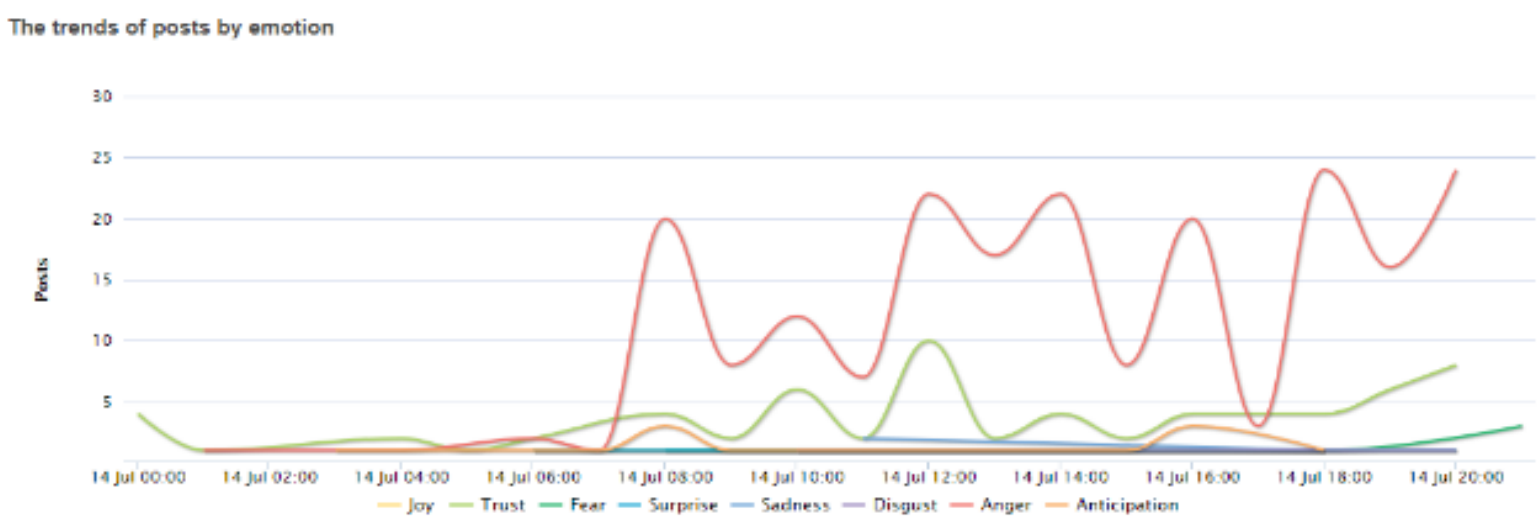

Figure 7: Anger (red) dominating sentiment graph

The anger (see figure 7) may originate from the disappointment of Islamist nationalism followers against the status-quo that is established by the followers of state-centric nationalism. On the other hand, adherents of national nationalism feel disturbed by the vision of Islamist nationalism who want to establish exclusive national sovereignty. Thus, it generates contesting imagination about the ideal concept of the nation, which both Islamist 
nationalism and state sponsored nationalism fail to meet an agreeable point. This may lead to entrenching primordial cleavages in the further nationalism development.

\section{Nationalism and Social Transformation in Indonesia}

Nationalism generally resides in public knowledge and agreement. In the past, the concept of nationalism tended to be formal, rigid, and had been narrated by the state. Now in the era of new media, public knowledge and the concept of nationalism have shifted a lot, especially in the virtual space. Aspinall (2015) divides nationalism into three, namely; economic nationalism, territorial nationalism, and cultural nationalism. Economic nationalism was marked by the economic crisis in 1998 as the country frequently imports, including importing rice (Aspinall, 2015). Territorial nationalism is defined as an effort to maintain the territorial integrity of the state from external aggression and internal separatism. Territorial nationalism is marked by efforts to protect Indonesian territories such as Papua and Aceh, including the issue of Timor Leste.

Cultural nationalism is marked by efforts to protect Indonesia's cultural heritage so that there are no claims from other countries. This cultural nationalism is shown by criticism and anger towards Malaysia towards Indonesia's cultural heritage and traditions such as dances, songs, culinary products, Ambonese songs, Batak dances, typical reog mask dances from East Java, and so on (Aspinall, 2015). Subsequently, Aspinall (2015) also explains the new characteristics of contemporary nationalism, namely non-ideological and non-intellectual. Aspinall's findings differ from the findings of our study in virtual space. Actors' contestation of nationalism in new media is very ideological and is played by intellectual actors.

The contestation of intellectual actors on social media is the actors are interconnected across networks. Actors are not only in the structure of physical communities but they become a virtual community-based community. These virtual communities imagine their closeness and togetherness with their respective narratives such as Khilafah, Pancasila, communism, nationalism, and so on. Actors and imaginary communities rest on virtual reality and not on empirical reality. This virtual reality slowly seeps into the imaginations of the connected individuals. This absorption of reality is exactly the same as what Benedict Anderson (2001) exemplifies about the fiction of Noli Me Tangere, where the fiction slowly seeps into reality, creating beliefs about the existence of a community with people who do not know each other.

Like actors and virtual communities who are involved in the contestation of nationalism, individuals imagine with each other their presence, existence, and even their "ideals" even though they are only in a virtual space. According to Anderson (2001), in the virtual society's imagination, the external image of nationalism is an imaginative external image. The word imaginative or imagined refers to the substance of the meaning that something can be imagined or imagined, even though in reality it never knows each other and meets each other. Anderson gave an example of an imagined political community, where an empirical community can transform into an imaginative political community when the concept of natural community is influenced by the concept of "an imagination about their togetherness". This togetherness comes with narratives and issues about nationalism with various interpretations.

In SNA data, we found that the issues of nationalism, related to the caliphate, PKI, communism, Pancasila, and so on increased dramatically. For those in power, the narrative about nationalism can be used as an effective tool to strengthen legitimacy (Zhongshi \& 
Huailin, 2007). In some cases, this dramatic and melodramatic event is able to arouse the spirit of nationalism such as defeats in soccer games, bomb events, conflicts between countries, and so on. These dramatic events now have become hyper-dramatic because of the reach of the new media with all its strength. Youths who do not know about the country's issues can quickly get angry and arouse a sense of nationalism and collective knowledge, only when the narrative that is constructed and produced on social media and online news. However, this narrative about nationalism and collective knowledge responses depends on how online news disseminates information and how people use that information.

The battle over nationalism in new media (social media and online reporting) is trapped in ambiguity and false debates. During and after the presidential election, online news tends to produce contents of populist nationalism. This is similar to what happened to the media in China; which are trapped in the narrative of populist nationalism by producing contents that promise income and present differently than formal nationalism (Zhongshi \& Huailin, 2007). In the context of China, the media pendulum becomes a place to struggle for space between profit orientation or fulfilling political interests (Huang \& Lee, 2003). In the Indonesian context, it is not much different from what happened in China, namely profit orientation and the contestation of political power in the media and virtual space.

\section{CONCLUSION}

This study aims to understand how nationalism is being reproduced and how actor contestation on the online news and social media in Indonesia after the Indonesia's 2019 presidential election. The data analysis shows that the production of nationalism content is dominated by populist nationalism and religious nationalism. Populist nationalism and religious nationalism are produced by intellectual-ideological actors. In contrast to the findings of Aspinall regarding new features of contemporary nationalism, namely nonideological and non-intellectual properties (Aspinall, 2015), this research points out that contemporary nationalism is played by intellectual and ideological actors such as Khilafah actors, professionals, and political elites. Contestations of intellectual actors on social media and media coverage are interconnected across networks. Actors and communities that intensively discuss the issue of nationalism are virtual-based actors and communities. These virtual actors and communities become "imagined political communities"; which they imagine their closeness and togetherness with the same issues and narratives. This research contributes to the study of nationalism in the new media era, by presenting big data from social media and online news. Since this research is limited to quantitative data and did not provide a more detailed analysis, it is suggested that future research examine the issue of nationalism in the new media era, in more detail.

\section{BIODATA}

Didik Haryadi Santoso is a Lecturer of Communication Science at the Universitas Mercu Buana Yogyakarta and a doctorate candidate at the Department of Communication Science, Faculty of Social and Political Sciences, Universitas Sebelas Maret (UNS) Surakarta, Indonesia. His research interests are new media and cyberculture.Email: didikhs@mercubuana-yogya.ac.id 


\section{REFERENCES}

Afaqi, M. Z. (2016). Melihat sejarah nasionalisme Indonesia untuk memupuk sikap kebangsaan generasi muda. Jurnal Civics: Media Kajian Kewarganegaraan, 13(2), 171187. https://doi.org/10.21831/civics.v13i2.12745

Aspinall, E. (2015). The new nationalism in Indonesia. Asia \& The Pacific Policy Studie, 3(1), 72-82. https://doi.org/10.1002/app5.111

Benedict, A. (2001). Imagined communities: Komunitas-komunitas terbayang. Yogyakarta: Insist Press.

Billig, M. (1995). Banal nationalism. London: Sage.

Bourchier, D. M. (2019). Two decades of ideological contestation in Indonesia: From democratic cosmopolitanism to religious nationalism. Journal of Contemporary Asia, 49(5), 713-733. https://doi.org/10.1080/00472336.2019.1590620

Edensor, T. (2002). National identity, popular culture and everyday life. New York: Berg Publishers.

Eriksen, T. H. (2007). Nationalism and the Internet. Nations and Nationalism, 13(1), 1-17. https://doi.org/10.1111/j.1469-8129.2007.00273.x

Foucault, M. (1988). Power knowledge. Random House.

Gellner, E. (1983). Nations and nationalism. Oxford: Basil Blackwell.

Guo, Z., Cheong, W. H., \& Chen, H. (2007). Nationalism as public imagination: The media's routine contribution to latent and manifest nationalism in China. International Communication Gazette, 69(5), 467-480. https://doi.org/fmcgit

Hadiz, V. R. (2016). Islamic populism in Indonesia and the Middle-East. New York: Cambridge University Press.

Hefner, R. W. (2001). Introduction: Multicultural and ctizenship in Malaysia, Singapore and Indonesia. In Author (Ed.), The politics of multiculturalism: Pluralism and citizenship in Malaysia, Singapore and Indonesia. Honolulu: University of Hawaii Press.

Hefner, R. W. (2018, August 20). Scaling up pluralism: Reflection towards \#2019 [Public lecture]. Yogyakarta: FISIPOL UGM.

Huang, Y., \& Lee, C.-C. (2003). Peddling party ideology for a profit: Chinese media and the rise of Chinese nationalism in the 1990s. In G. D. Rawnsley \& M.-Y. T. Rawnsley (Eds.), Political communications in Greater China: The construction and reflection of identity (pp. 41-61). London: Routledge.

Humeira, B., \& Sarwono, B. (2019). Religious-social shaping of technology approach to internet use by an urban Islamic group in Indonesia. Jurnal Komunikasi: Malaysian Journal of Communication, 35(4), 69-82. https://doi.org/gdp8

Hurgronje, Snouck (1994). Kumpulan karangan Snouck Hurgronje. Jakarta: INIS.

Hyun, K. D., \& Kim, J. (2015). The role of new media in sustaining the status quo: Online political expression, nationalism, and system support in China. Information, Communication \& Society, 18(7), 766-781. https://doi.org/gc7m2i

Kecmanovic D. (1996) What Is nationalism?. In D. Kecmanovic (Ed.), The mass psychology of ethnonationalism (pp. 15-78). Springer. https://doi.org/gk4f

Kusumawardani, A., \& Faturochman. (2004). Nasionalisme. Bulletin Psikologi, 12(2).

Mietzner, M. (2013) Fighting the hellhounds: Pro-democracy activists and party politics in post-Suharto Indonesia. Journal of Contemporary Asia, 43(1), 28-50. https://doi.org/10.1080/00472336.2012.735919 
Mietzner, M. (2020). Rival populism and the democratic crisis in Indonesia: Chauvinists, Islamists and technocrats. Australian Journal of International Affairs, 74(4), 420-438. https://doi.org/10.1080/10357718.2020.1725426

Nadzir, I., Seftiani, S., \& Permana, Y. S. (2019, November 5). Hoax and misinformation in Indonesia: Insights from a nationwide survey. ISEAS Perspectives, 92, 1-12.

Ramage, D. (1996). INDONESIA AT 50: Islam, Nationalism (and Democracy?). Southeast Asian Affairs, 147-165. http://www.jstor.org/stable/27912151

Tirtosudarmo, R., \& Hadi, A. (2018). Jakarta, on the brink of being a divided city? Ethnicity, media and social transformation 1. In T. Caponio, P. Scholten, \& R. Zapata-Barrero. (Eds.), The Routledge handbook of the governance of migration and diversity in cities (Part V, Chap. 25, 1st ed.). New York: Routledge.

Tsai, Y.-L. (2011). Spaces of exclusion, walls of intimacy: Rethinking "Chinese exclusivity" in Indonesia. Indonesia, 92, 125-155.

Utomo, M. R. (2020). Geopolitical bodies: Media discourse on the Indonesian national identity. Jurnal Komunikasi: Malaysian Journal of Communication, 36(1), 449-464. https://doi.org/10.17576/JKMJC-2020-3601-26

Wang, X., \& Kobayashi, T. (2020). Nationalism and political system justification in China: Differential effects of traditional and new media. Chinese Journal of Communication, 14(2), 139-156. https://doi.org/10.1080/17544750.2020.1807372 